\title{
Antioxidant Effects of Protocatechuic Acid, Ferulic Acid, and Caffeic Acid in Human Neutrophils Using a Fluorescent Substance
}

\author{
Efectos Antioxidantes del Ácido Protocatéquico, Ácido Ferúlico y el Ácido Caféico \\ usando una Sustancia Fluorescente en los Neutrófilos Humanos
}

"Akiyo Hyogo; ${ }^{* * *}$ Toshihiro Kobayashi; **Eva Garcia del Saz \& *Harumichi Seguchi

HYOGO, A.; KOBAYASHI, T.; GARCIA DEL SAZ, E. \& SEGUCHI, H. Antioxidant effects of protocatechuic acid, ferulic acid, and caffeic acid in human neutrophils using a fluorescent substance. Int. J. Morphol., 28(3):911-920, 2010.

SUMMARY: Human neutrophils stimulated by phorbol myristate acetate (PMA), an activator of protein kinase C, produce active oxygen by NADPH oxidase in intracellular structures. We added succinimidyl ester of dichlorodihydrofluorescein diacetate ( $\mathrm{H}_{2}$ DCFDA), which first emits fluorescence when oxidized with active oxygen species, to neutrophils to produce active oxygen, in order to investigate the antioxidant effects of protocatechuic acid, ferulic acid, and caffeic acid which belong to polyphenols and are widely distributed among plants. Particularly, we focused on examining whether these substances capture and eliminate active oxygen inside or outside the neutrophil cytoplasm and whether these substances inhibit NADPH oxidase. Fluorescence microscopy demonstrated that fluorescence-positive intracellular structures were decreased in neutrophils when stimulated by PMA and exposed to an antioxidant. Quantitative measurement by flow cytometry revealed that the fluorescence intensities in neutrophils, exposed to protocatechuic acid, ferulic acid, or caffeic acid, were decreased by $62.9 \%, 71.4 \%$, and $86.1 \%$, respectively, as compared with those stimulated by PMA but not exposed to an antioxidant. Judging from fluorescence microscopy and dot blots by flow cytometry, these antioxidants had no effects on neutrophil morphology. On the other hand, the fluorescence intensities of the active oxygen released from neutrophils were decreased by $81.4 \%, 46.7 \%$, and $27.4 \%$, respectively. Diphenylene iodonium, a specific inhibitor of NADPH oxidase, inhibited the enzyme by $92.1 \%$ in the PMA-stimulated neutrophils. Protocatechuic acid, ferulic acid, and caffeic acid inhibited the enzyme by $36.5 \%, 54.6 \%$, and $27.4 \%$, respectively. These results demonstrate that protocatechuic acid, ferulic acid, and caffeic acid capture and eliminate active oxygen, produced by PMA-stimulated neutrophils, intracellularly and extracellularly. Furthermore, these antioxidants partially inhibit NADPH oxidase activity.

KEY WORDS: Antioxidant effects; Polyphenols; Human neutrophils; Flow cytometry.

\section{INTRODUCTION}

Neutrophils are a type of white blood cell and play a major role in host defense against bacterial infection. An important part of this defense mechanism is the production of active oxygen and its reactive derivatives (e.g., hydrogen peroxide, hydroxyl group, and singlet oxygen) by NADPH oxidase, an activated specific enzyme system (Babior, 1978; Robinson \& Badway, 1995; Kobayashi et al., 1998). Kobayashi et al. reported that, following PMA stimulation, active oxygen is produced in the intracellular compartments, of human neutrophils. First active oxygen is noted in short rod-shaped granules. These active oxygen-producing granules directly fuse to plasma membrane or form large endocytic vacuoles to bind to plasma membrane (Kobayashi et al., 1998). This phenomenon causes the extracellular release of active oxygen and its related free radicals to destroy normal essential components of human body, such as cells, tissues, and metabolic pathways, and cause various diseases (Babior, 1978; Kobayashi et al., 1998; Kobayashi \& Seguchi, 1999; Babior, 1999). Also, we reported a simple method to elucidate the production of active oxygen within neutrophils

\footnotetext{
* Department of Anatomy and Physiology, Graduate School of Life Science, Kobe Women's University.

** Center for Regional and International Collaboration, Kochi University.

*** Department of Physiotherapy, Faculty of Rehabilitation, Kobe International Universitity.
} 
by applying succinimidyl ester of dichlorodihydrofluorescein diacetate that first emits fluorescence when oxidized by active oxygen species (H DCFDA) (Robinson, 1988). In PMAstimulated neutrophils, the production of active oxygen can be fluoroscopically observed directly as a fluorescencepositive structure (Kobayashi et al., 2000). Thus, fluorescence intensity can be measured by this method using flow cytometry.

Our objective was to examine the antioxidant effects of three kinds of polyphenols. Specifically, protocatechuic acid (PCA, 3,4-dihydroxy-benzoic acid, $\mathrm{C}_{7} \mathrm{H}_{6} \mathrm{O}_{4}$, MW154.120) (Nakamura et al., 2000; Lin et al., 2007), ferulic acid (FA, 3(4-hydro-3-methoxy-phenyl) prop-2-enoic acid, $\mathrm{C}_{10} \mathrm{H}_{10} \mathrm{O}_{4}, \mathrm{MW} 194.184$ ) (Kern et al., 2003; Kwon et al., 2009), and caffeic acid (CA, 3-3, 4-dihydroxyphenyl 2propenoic acid, $\mathrm{C}_{9} \mathrm{H}_{8} \mathrm{O}_{4}, \mathrm{MW} 180.16$ ) (Kern et al; Konishi \& Kobayashi, 2004)) are widely distributed among plants, including edible plants (Sakakibara et al., 2003). These are classified into an aromatic hydroxy group. Protocatechuic acid is a polyphenol, belonging to dihydroxy acid derivatives. Ferulic and caffeic acids are hydroxycinnamic acid derivatives. These are lignin components whose antioxidant and anticancer effects are known (Nishikawa et al., 2008). This study examined the antioxidant effects of these three kinds of polyphenols to elucidate which polyphenol captures and eliminates active oxygen, whether this phenomenon occurs intracellularly or extracellularly, and whether NADPH oxidase is inhibited by these substances.

\section{MATERIAL AND METHOD}

Cell isolation. Human neutrophils were collected from healthy adult females after informed consent was obtained. This study was approved by the Human Research Ethics Committee of Kobe Women's University (approval No.192). As described previously (Kobayashi \& Robinson, 1991; Kobayashi et al., 1998), neutrophils were separated from peripheral blood by 30 -minute precipitation using $0.5 \%$ citric acid as an anticoagulant and 6\% dextran, and then the remaining erythrocytes were removed by hemolysis in a hypotonic solution. In addition, the cells were centrifuged and concentrated using Histopaque. Cell viability was at least $98 \%$ by trypan blue exclusion. Neutrophils accounted for $95 \%$ of the cells by differential counting. The cells were stored in phosphate buffered saline (PBS) until use.

Cell stimulation. Human neutrophils were stimulated with PMA, an activator of protein kinase C (Nishizuka, 1986), at $37^{\circ} \mathrm{C}$ for 1 minute. Then, a reaction solution to detect an oxidizing agent was added. The stock solution (1 mg PMA) was prepared with $0.5 \mathrm{ml}$ of a DMSO fusion solution and stored at $-20^{\circ} \mathrm{C} .1 \times 10^{6}$ cells $/ \mathrm{ml}$ were suspended in PBS and exposed to $50 \mathrm{ng} / \mathrm{ml} \mathrm{PMA}$ at $37^{\circ} \mathrm{C}$. A PMA stock solution was diluted with DMSO; the final concentration of the solvent in a cell suspension was $0.25 \%(\mathrm{v} / \mathrm{v})$. Unstimulated cells were used as a control to be exposed to culture reaction without $1 \%$ PMA.

Addition of $\mathrm{H}_{2}$ DCFDA, and protocatechuic acid, ferulic acid, or caffeic acid. Cell suspensions ( 5 x 106 cells/ml in PBS excluding $\mathrm{Mg}^{++}$and $\mathrm{Ca}^{++}$) were added to solutions containing $25 \mathrm{mM} \mathrm{H}$ DCFDA and $0.1 \mathrm{mM}$ protocatechuic acid, ferulic acid, or caffeic acid with stirring slowly at $20^{\circ} \mathrm{C}$ for 20 minutes and finally centrifuged. DMSO was used as a solvent for $\mathrm{H}_{2}$ DCFDA and protocatechuic acid, ferulic acid, and caffeic acid. The final concentration of $\mathrm{H}_{2}$ DCFDA was $0.25 \%(\mathrm{v} / \mathrm{v})$. The concentrations of protocatechuic acid, ferulic acid, and caffeic acid were $0.1 \mathrm{mM}$. In neutrophils exposed to these solutions, no endocytosis was observed. After exposure, a neutrophil pellet after centrifugation was suspended and stored in PBS (excluding $\mathrm{Mg}^{++}$and $\mathrm{Ca}^{++}$) until use for fluorescence microscopy or flow cytometry (Kobayashi et al., 2000).

Fluorescence microscopy. Neutrophils exposed to $\mathrm{H}_{2}$ DCFDA and protocatechuic acid, ferulic acid, or caffeic acid were placed in dishes (MatTek, Ashland, MA, USA) with poly-L-lysine-coated cover glasses placed at the bottom of $35-\mathrm{mm}$ diameter microwell dishes, at $20^{\circ} \mathrm{C}$ for two minutes, and were subsequently washed with PBS. A buffer preheated at $37^{\circ} \mathrm{C}$, into which neutrophils had been added beforehand, was poured into a $2 \mathrm{ml}$ petri dish, and the dish was placed on the stage of a fluorescence microscope (Axiovert S100TV, Carl Zeiss, Jena, Germany) and kept at $37^{\circ} \mathrm{C}$. The microscope was equipped with a CCD camera C4880 (Hamamatsu Photonics, Hamamatsu, Japan), a 100 w mercury lamp, and a suitable filter set. The exposure time of the CCD camera for fluorescence photography was 0.2 second. Fluorescence-positive intracellular structures were analyzed using image analysis software (Hamamatsu Photonics, Hamamatsu, Japan).

Measurement of NADPH oxidase activity using NADPH as a substrate. Neutrophils $\left(1 \times 10^{7}\right.$ cells $\left./ \mathrm{ml}\right)$ were homogenized in a ice-cold buffer $(0.32 \mathrm{M}$ sucrose, $4 \mathrm{mM}$ HEPES, $5 \mu \mathrm{M}$ aprotinin, $20 \mu \mathrm{M}$ leupeptin, and $1 \mu \mathrm{M}$ pepstatin, $\mathrm{pH} 7.4$ ) (sonicated at $90 \%$ amplitude three times for 5 seconds) using Ultrasonic Processor UP50H (Stahnsdorf, Germany). A culture buffer (20 mM HEPES, $135 \mathrm{mM} \mathrm{NaCl}, 5 \mathrm{mM} \mathrm{KCl}, 5 \mu \mathrm{M}$ aprotinin, $20 \mu \mathrm{M}$ leupeptin, and $1 \mu \mathrm{M}$ pepstatin, $\mathrm{pH} 7.4$ ) was added to the homogenate ( 1 x $10^{6}$ cells $\left./ \mathrm{ml}\right)$. The reaction was initiated by adding NADPH $(100 \mu \mathrm{M})$ to the culture buffer at $37^{\circ} \mathrm{C}$. NADPH 
oxidase activity was determined by measuring the luminosity changes of NADPH at $340 \mathrm{~nm}$ using Hitachi 220A Spectrophotometer (Hitachi, Tokyo, Japan). As a control experiment, diphenyleneiodonium, a specific inhibitor of NADPH oxidase, was used (Doussière \& Vignais, 1992).

Measurement of intracellular active oxygen $\left(\mathrm{O}_{2}^{-}\right)$by flow cytometry. To a cell suspension in PBS $\left(1 \times 10^{6}\right.$ cells $\left./ \mathrm{ml}\right)$, $25 \mathrm{mM}$ succinimidyl ester of dichlorodihydrofluorescein diacetate $\left(\mathrm{H}_{2} \mathrm{DCFDA}\right)$ was added. The cell suspension was stirred at $20^{\circ} \mathrm{C}$ for 20 minutes and centrifuged (Kobayashi et al., 2000). The fluorescence intensity of the cell suspension in a 3-ml test tube, to which $\mathrm{H}_{2}$ DCFDA was added, was measured at a emission wavelength of $488 \mathrm{~nm}$ by Flow Cytometry FACScan (Becton Dickinson, San Jose, CA, USA),. Fluorescence was detected using a green fluorescence channel.

Measurement of extracellular active oxygen $\left(\mathrm{O}_{2}^{-}\right)$. The active oxygen (O2-) released extracellularly was determined by measuring the elimination of cytochrome c by SOD with a spectrophotometer (McCord \& Fridovich, 1969). Briefly, neutrophils put into a $3-\mathrm{ml}$ cuvette were stimulated with PMA and maintained in a temperature-controlled cuvette at $37^{\circ} \mathrm{C}$. The cuvette contained $50 \mathrm{ng} / \mathrm{ml}$ PMA, $0.1 \mathrm{mM}$ cytochrome c, $1 \times 10^{6}$ cells $/ \mathrm{ml}$, and the same ingredients as those of PBS. A reference cuvette contained the same ingredients as above and $60 \mathrm{mg} / \mathrm{ml} \mathrm{SOD}$. Cytochrome $\mathrm{C}$ and SOD were added to the reaction mixture 1 minute before PMA addition. The decrease in cytochrome c was measured with Hitachi 220A Spectrophotometer (Hitachi, Tokyo, Japan). Absorbance change (A) at a wavelength of $550 \mathrm{~nm}$ was measured (Messey, 1959).

\section{RESULTS}

Effects of antioxidants on active oxygen production in human neutrophils. To detect fluorescence generated by an oxidizing agent in human neutrophils, neutrophils were allowed to react with $\mathrm{H}_{2}$ DCFDA, an detection reagent of oxidizing agent. This reagent readily permeates neutrophils, and thus was used to visualize and quantitatively detect an intracellular oxidizing agent. No fluorescence generated by $\mathrm{H}_{2}$ DCFDA was observed in unstimulated neutrophils (data not shown). In PMA-stimulated cells, to which H2DCFDA was added, fluorescence was seen in the intracellular structures throughout the neutrophil cytoplasm (Fig. 1-1A). Adding an antioxidant (protocatechuic acid, ferulic acid, or caffeic acid) to PMA-stimulated cells, to which $\mathrm{H}_{2}$ DCFDA was added, decreased intracellular fluorescence intensities (Figs. 1-1B, 1-2C, and 1-2D). Fluorescence attenuation due to the antioxidants was quantitatively determined by flow cytometry. The antioxidants markedly decreased fluorescence intensity in cells to which $\mathrm{H}_{2}$ DCFDA was added (Fig. 2). The fluorescence generated by active oxygen was inhibited by protocatechuic acid, ferulic acid, and caffeic acid by $62.9 \%, 71.4 \%$, and $86.1 \%$, respectively (Table I). These findings demonstrate that these antioxidants could permeate neutrophils to inhibit oxide production in neutrophils.

Effects of antioxidants on neutrophil morphology. We examined whether antioxidants had effects on the morphological changes in human neutrophils. As shown in Figures 1-1 and 1-2, the light-microscopic findings showed no morphological changes in PMA-stimulated cells to which protocatechuic acid, ferulic acid, or caffeic acid was added (Figs. 1-1, 1-2). The dot blots obtained from forward and lateral scatterings by flow cytometry demonstrated no difference between the neutrophil distributions with or without addition of an antioxidant, showing similar distribution patterns (Figure 3). Furthermore, no difference was noted in a viability test by trypan blue exclusion between neutrophils with or without addition of an antioxidant (data not shown). These findings suggest that the antioxidant had no effects on the morphology or viability of PMA-stimulated neutrophils to which an antioxidant was added.

Effects of antioxidants on the extracellular active oxygen from neutrophils. We measured decreased ferrocytochrome c, due to SOD inhibition, using a spectrophotometer to examine the capturing and eliminating effects of an antioxidant on the active oxygen released extracellularly from neutrophils. Ferrocytochrome c does not permeate neutrophils. Hence, this method is used to determine the quantity of extracellular oxidizing agent. The quantity of

Table I. Scavenging effects of antioxidants, protocatechuic acid, ferulic acid and caffeic acid on superoxide produced intracellularly by the $\mathrm{H}_{2}$ DCFDA-loaded neutrophils stimulated with PMA are $476.5 \pm 58.3(62.9 \%), 367.1 \pm 44.3(71.4 \%), 179.6 \pm 29.5(86.1 \%)$ respectively, in comparison

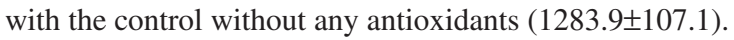

\begin{tabular}{lcc}
\hline Conditions & Fluorescence intensity (mean) & Inhibition $(\%)$ \\
\hline PMA & $1283.9 \pm 107.1$ & - \\
\hline+ Protocatechuic acid & $476.5 \pm 58.3$ & 62.9 \\
+ Ferulic acid & $367.1 \pm 44.9$ & 71.4 \\
+ Caffeic acid & $179.6 \pm 29.5$ & 86.1 \\
\hline
\end{tabular}



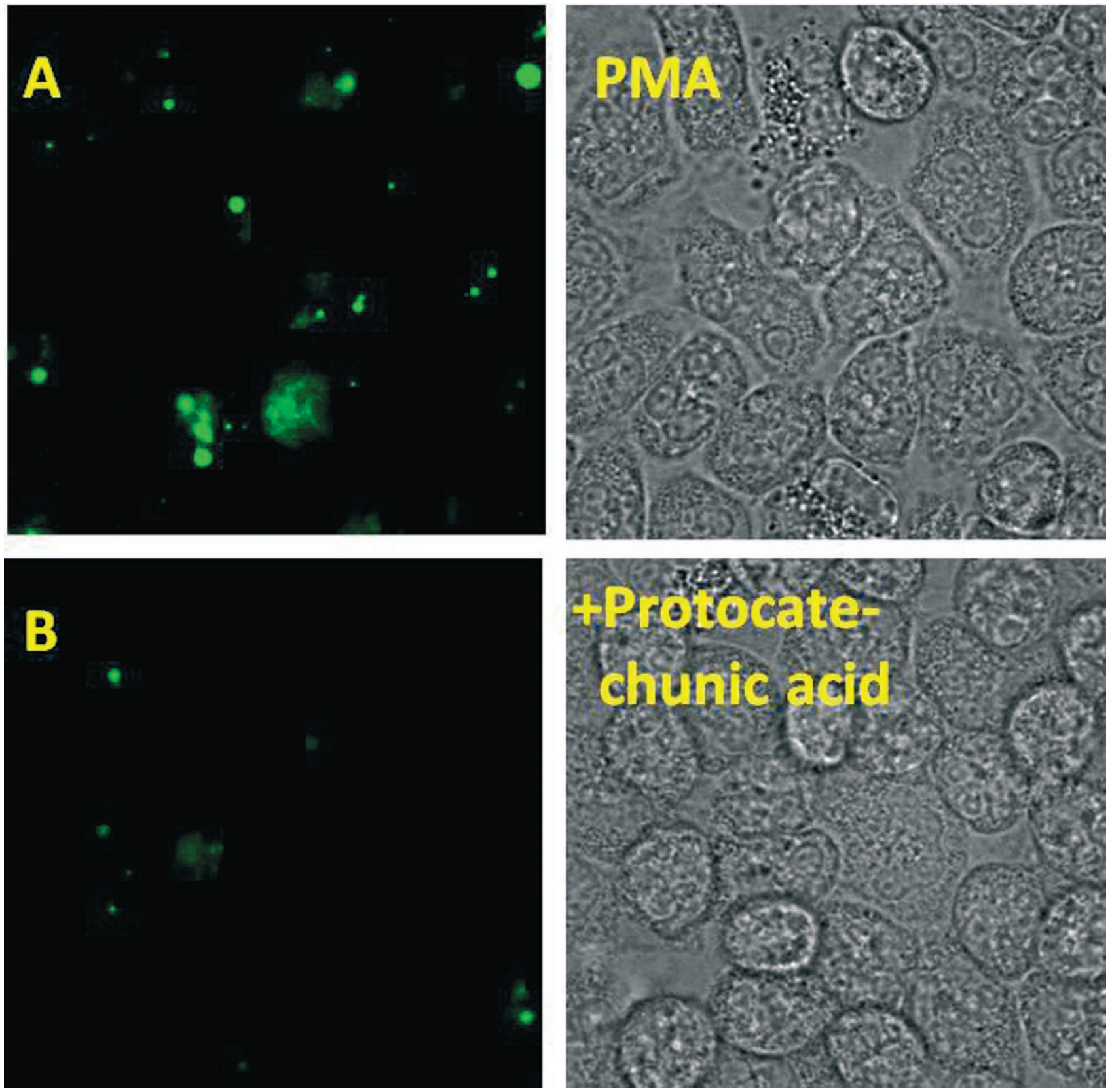

Fig. 1-1 Localization of superoxide-producing sites in neutrophils stimulated with PMA. A: When H2DCFDA-loaded cells were stimulated with PMA, fluorescence was visualized in intracellular compartments distributed throughout the cytoplasm of the neutrophils. B: Intensity of the fluorescence decreased in the stimulated H2DCFDA-loaded cells exposed to protocatechuic acid.

Table II. Scavenging effects of antioxidants, protocatechuic acid, ferulic acid and caffeic acid on superoxide released extracellularly by neutrophils stimulated with PMA were $0.59 \pm 0.20$ $(81.4 \%), 1.69 \pm 0.35(46.7 \%), 0.73 \pm 0.16(77.0 \%)$ respectively, in comparison with the control (3.17 \pm 0.81$)$. Protocatechuic acid showed strongest scavenging effect against extracellular oxidants.

\begin{tabular}{lcc}
\hline Conditions & $\begin{array}{c}\text { Superoxide production } \\
\left(\mathrm{n} \mathrm{mol} / \mathrm{min} / 1 \times 10^{6} \text { Cells }\right.\end{array}$ & $\begin{array}{c}\text { Inhibition } \\
(\%)\end{array}$ \\
\hline + PMA & $3.17 \pm 0.81$ & - \\
+ Protocatechuic acid & $0.59 \pm 0.21$ & 81.4 \\
+ Ferulic acid & $1.69 \pm 0.35$ & 46.7 \\
+ Caffeic acid & $0.73 \pm 0.16$ & 77.0 \\
\hline
\end{tabular}



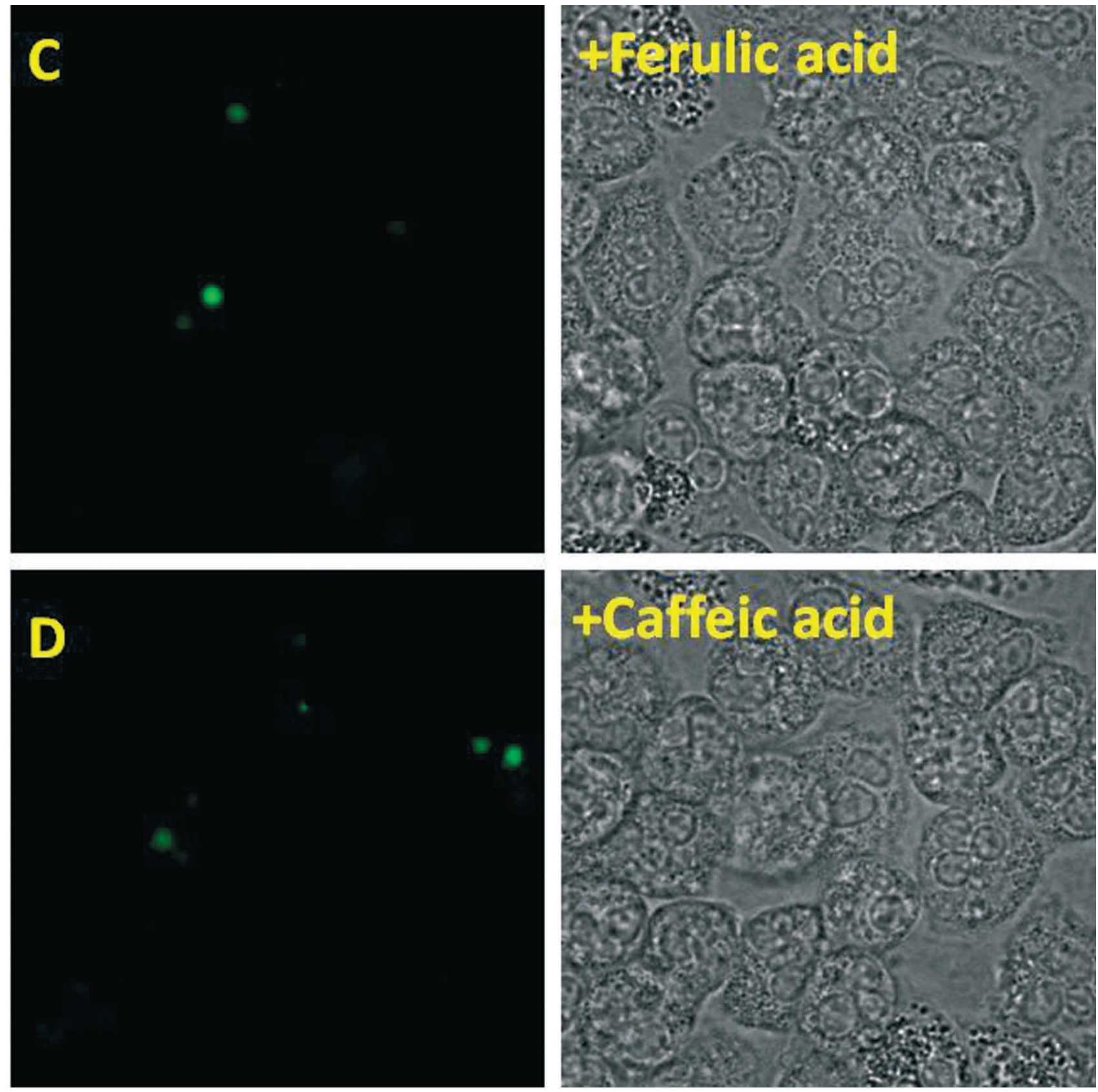

Fig. 1-2 Localization of superoxide-producing sites in neutrophils stimulated with PMA. Intensity of the fluorescence decreased in the stimulated $\mathrm{H}_{2}$ DCFDA-loaded cell exposed to ferulic acid (C), and caffeic acid (D).

extracellular active oxygen released from PMA-stimulated neutrophils was $3.17 \pm 0.81 \mathrm{nmol} / \mathrm{min} / 1 \times 10^{6}$ cells (Table II). The fluorescence intensities of extracellularly-released active oxygen, captured by protocatechuic acid, ferulic acid, and caffeic acid, were decreased by $81.4 \%, 46.7 \%$, and $77.0 \%$, respectively (Table II). These findings demonstrate that the antioxidants used in this study inhibited the active oxygen generated from neutrophils both intracellularly and extracellularly.

\section{Effects of antioxidants on NADPH oxidase of neutrophils.} We examined the direct inhibitory effects of antioxidants on NADPH oxidase activity using the crude extracts of PMAstimulated human neutrophils. Diphenylene iodonium, a specific inhibitor of the NADPH oxidase activity, was used as a control of this experiment (Doussière \& Vignais).

As expected, this reagent inhibited the NADPH oxidase activity ( $92.1 \%$ inhibition) (Table III). The antioxidants 
used in this study also inhibited the enzyme activity. However, the inhibitory effects were weaker than those of diphenyleneiodonium; protocatechuic acid, ferulic acid, and caffeic acid inhibited the enzyme by $36.5 \%, 54.6 \%$, and
$27.4 \%$, respectively (Table III). Thus, the antioxidants used in this study were found to capture and eliminate active oxygen inside and outside neutrophils to different degrees, and inhibit NADPH oxidase activity.

Table III. Inhibitory effects of antioxidants on NADPH oxidase activity in neutrophils stimulated with PMA. The inhibitory rates of protocatechuic acid, ferulic acid, and caffeic acid were $36.5 \%$, $54.6 \%$, and $27.4 \%$ respectively. Ferulic acid showed the highest inhibitory effect.

\begin{tabular}{lcc} 
Conditions & $\begin{array}{c}\text { Oxidized NADPH } \\
\left(\mathrm{n} \mathrm{mol} / \mathrm{min} / 1 \times 10^{6} \mathrm{Cells}\right)\end{array}$ & $\begin{array}{c}\text { Inhibition } \\
\%\end{array}$ \\
\hline + Protochatec hunic acid & $102.7 \pm 19.0$ & 36.5 \\
+ Ferulic acid & $73.4 \pm 5.8$ & 54.6 \\
+ Caffeic acid & $117.4 \pm 17.7$ & 27.4 \\
+ Diphenylene iodonium & $12.8 \pm 3.4$ & 92.1
\end{tabular}
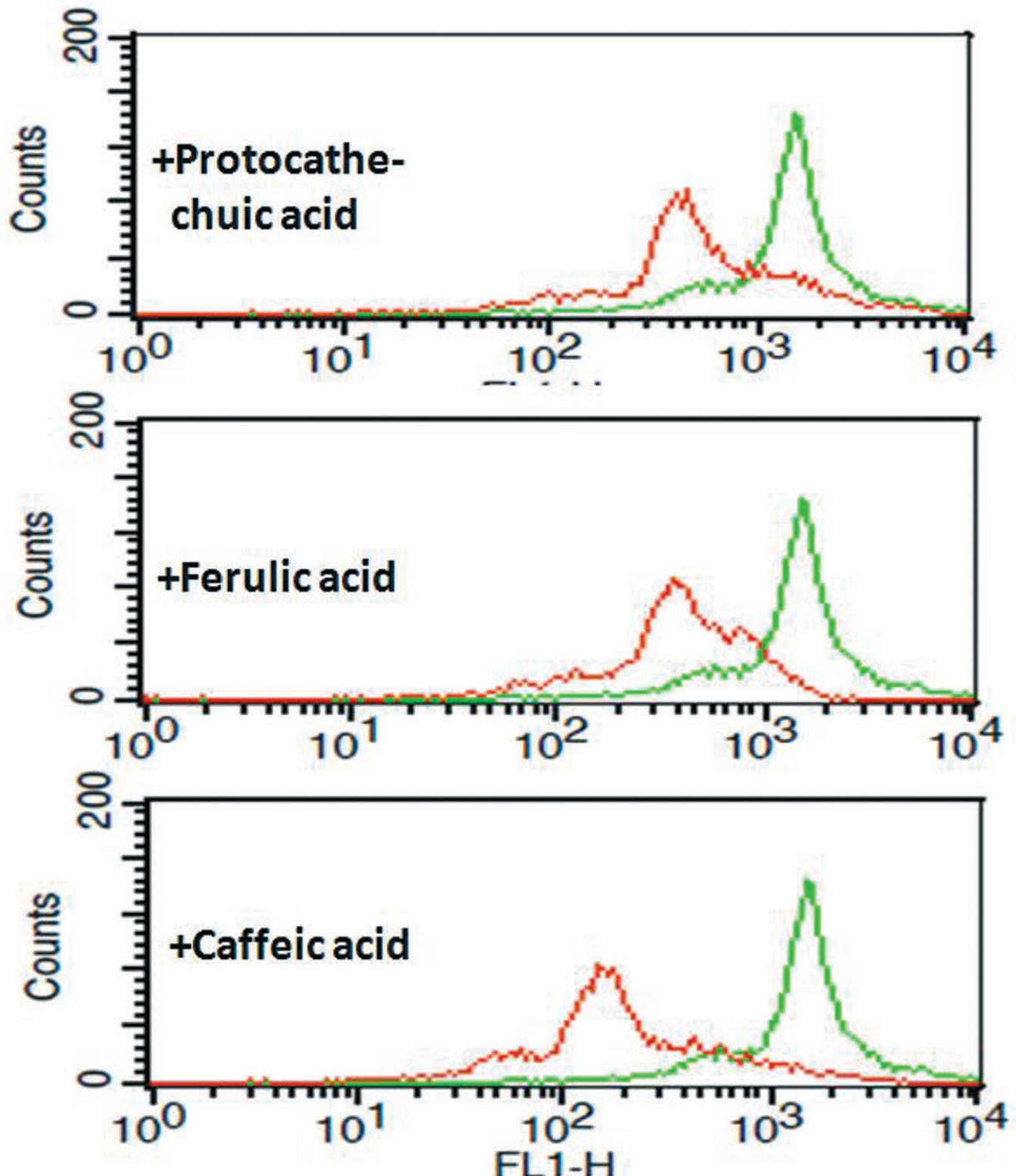

Fig. 2 Quantitative assays of scavenging effect of antioxidants on superoxide produced intracellularly by neutrophils stimulated with PMA. The fluorescence caused by superoxide was strongly suppressed by protocatechuic acid, ferulic acid, and caffeic acid, shown with red lines. The green line shows the intensity of fluorescence generated in the $\mathrm{H}_{2}$ DCFDA-loaded cells treated with solely with PMA. 

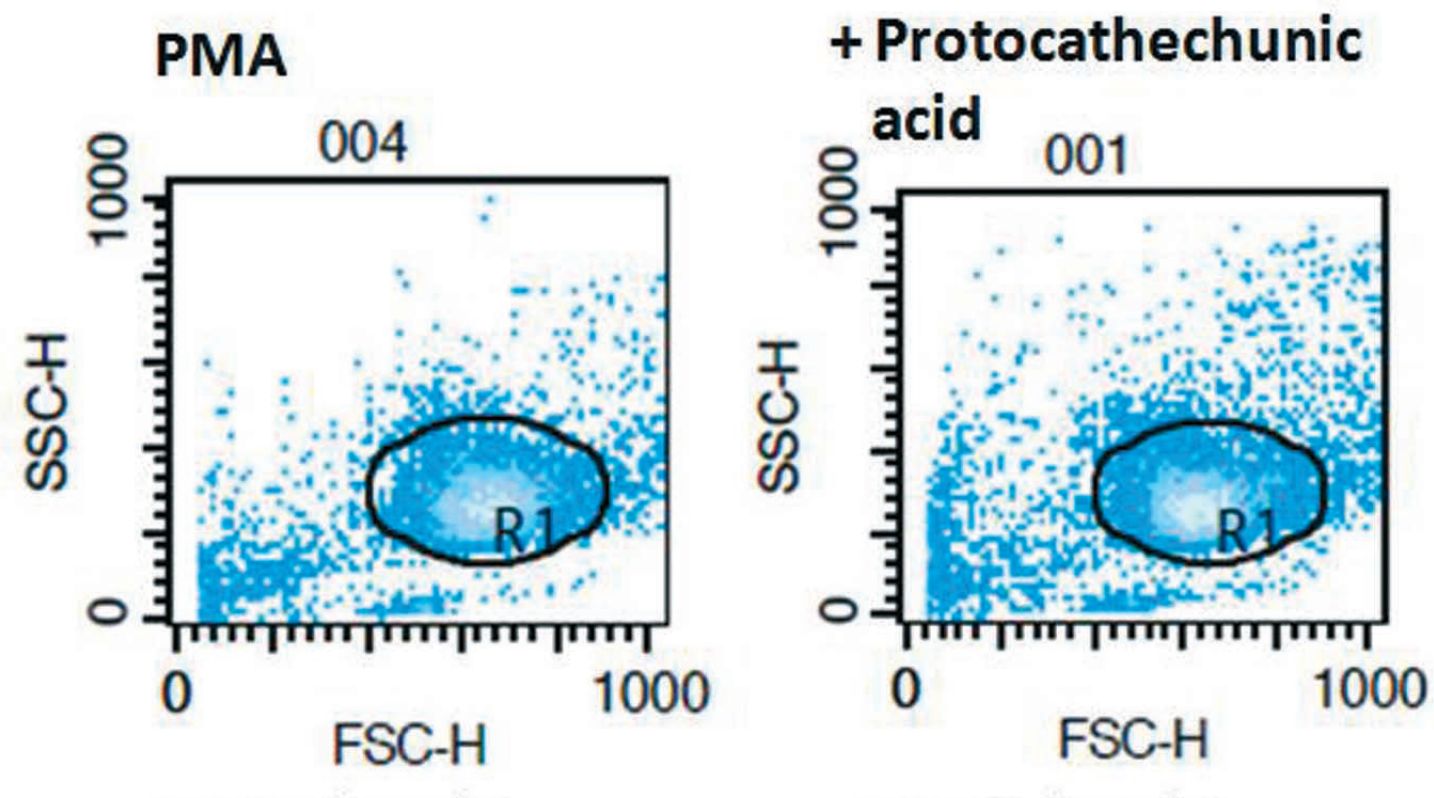

+ Ferulic acid

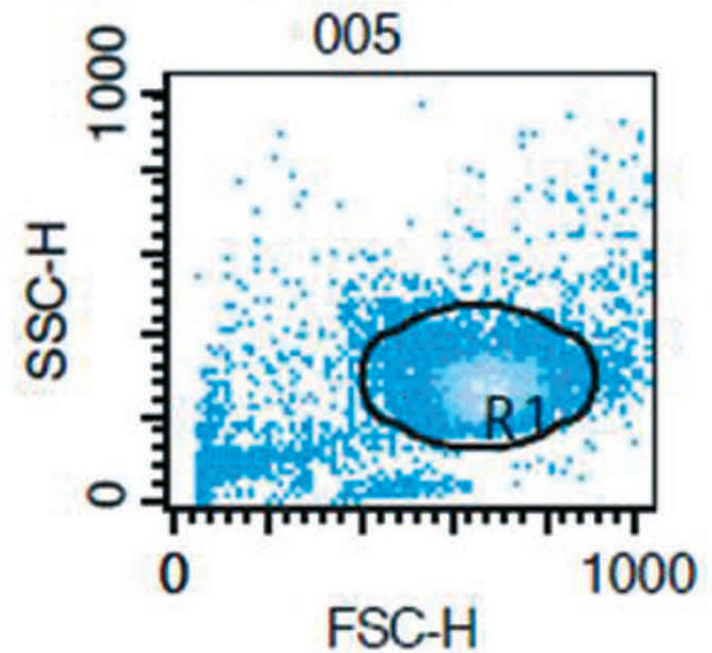

\section{+ Caffeic acid}

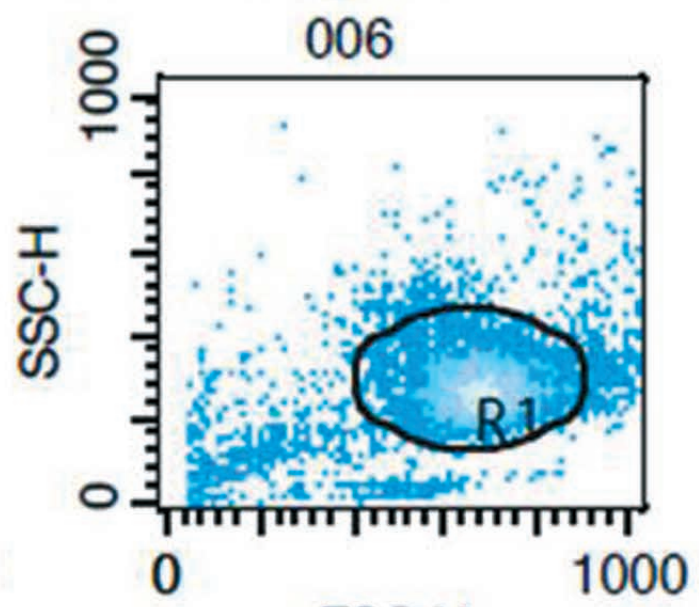

FSC-H

Fig. 3 Detection of Forward Scatter (FSC) and Side Scatter (SSC) in neutrophils stimulated with PMA.

\section{DISCUSSION}

Neutrophils play an important role in the biological defense against infection. The central role of this biological defense is to produce active oxygen and its derivatives (i.e., hydrogen peroxide, hydroxyl group, and singlet oxygen) and is associated with NADPH oxidase, This enzyme consists of three cytoplasmic factors (p40-phox, p47-phox, and p67phox) and two membrane factors (p22-phox and gp91-phox) (also called cytochrome b558) (Babior, 1999; Kobayashi \& Seguchi, 1999; Kobayashi et al., 2001). Stimulation with
PMA, an activator of protein kinase $\mathrm{C}$, phosphorylates and structurally changes the cytoplasmic factors, which together bind to the membrane factors, resulting in the formation of NADPH oxidase and the production of active oxygen. Here, two GTP-binding proteins (Rap1A and p21-rac) regulate the production of active oxygen. In non-activated neutrophils, p21-rac forms a cytoplasmic complex with a Rho-GDP dissociation inhibitor (i.e., GDI) and is separated from RhoGDI by cell stimulation to bind to p61-phox. Rap1A strongly 
binds to cytochrome b558 to inhibit the production of active oxygen and function as a final trigger involved in direct interaction with cytochrome b558 (Kobayashi \& Seguchi). Formerly, NADPH oxidase was considered to exist in the plasma membrane of neutrophils. In stimulated neutrophils, the cytoplasmic factors of NADPH oxidase bind to the membrane factors. Kobayashi et al. (1998) detected active oxygen directly using an enzyme histochemical technique with 3,3'-diaminobennzidine and manganese (DAB/Mn). NADPH oxidase, PMA-stimulated using cationized ferritin as a label to detect the plasma membrane, is localized in the limiting membrane of rod-shaped compartments in neutrophils. NADPH oxidase activity is induced on the cell surface to be released from cells by exocytosis from secretory granules. Hence, the released active oxygen damages surrounding normal tissues and cells to cause various abnormalities, such as infection, arteriosclerosis, and malignant tumors.

We reported a simple method to examine the dynamics of the intracellular compartments that produce active oxygen in cytoplasm (Kobayashi et al., 2000). In this method, $\mathrm{H}_{2}$ DCFDA that first emits fluorescence when oxidized by active oxygen is added to neutrophils. In PMAstimulated human neutrophils, fluorescence-emitting intracellular compartments are observed. When the H2DCFDA is used, the survival time of neutrophils is 3.5 hours in ice-cold or $37^{\circ} \mathrm{C} \mathrm{PBS}$, providing sufficient time to conduct necessary studies (Kobayashi et al., 2000). Also, the mitochondria of neutrophils are known to produce active oxygen species (Freeman and Crapo, 1982; Cross and Jones, 1991). These fluorescence-positive structures are not mitochondria (Kobayashi et al., 2000). Thus, this method for labeling active oxygen production allows measurement of fluorescence intensities inside and outside neutrophils by fluorescence microscopy and flow cytometry (Kobayashi et al., 2000). Figures 1-1A and 1-1B, phase-contrast micrographs (Figures 1-2C and 1-2D, left), and dot blots showing intensities of forward (FSC-H) and side (SSC-H) scatterings by flow cytometry (Fig. 3) demonstrate that the antioxidants used in this study (protocatechuic acid, ferulic acid, and caffeic) readily enter neutrophils without effects on neutrophil morphology.

As shown in Figure 1-1A, most human neutrophils only stimulated by PMA had many fluorescence-positive vesicles and vacuoles dispersed in the cytoplasm. In samples to which protocatechuic acid, ferulic acid, or caffeic acid was added, the number of fluorescence-positive granules in neutrophil cytoplasm was decreased (Figs. 1-1B, 1-2C, and 1-2D). Comparison of fluorescence intensities in the neutrophil cytoplasm of the samples to which protocatechuic acid, ferulic acid, or caffeic acid was added with those to which no oxidant scavenger was added showed that active oxygen was decreased by $62.9 \%, 71.4 \%$, and $86.1 \%$, respectively, suggesting that caffeic acid had the strongest eliminating effects (Figs. 1-2D and 2, Table I). Protocatechuic acid, caffeic acid, and ferulic acid eliminated $81.4 \%, 46.7 \%$, and $77.0 \%$ of the active oxygen released from neutrophils (Table II); protocatechuic acid had the strongest eliminating effects. Diphenylene iodonium, a specific inhibitor of NADPH oxidase, inhibited the enzyme by $92.1 \%$. As described in Table III, protocatechuic acid, ferulic acid, and caffeic acid inhibited NADPH oxidase by $36.5 \%, 54.6 \%$, and $27.4 \%$, respectively. Thus, ferulic acid had the strongest inhibitory effects.

All the polyphenols examined here are ubiquitously contained in vegetable cell walls. They belong to hydroxy acid and all have relatively simple structural formulas, and eliminate active oxygen. Caffeic acid had the strongest eliminating effects on intracellular active oxygen, while protocatechuic acid effectively eliminated extracellular active oxygen. Ferulic acid had the strongest inhibitory effects on NADPH oxidase. In addition, the $\mathrm{H}_{2}$ DCFDA used to label active oxygen in this study could specifically detect active oxygen production by emitting fluorescence when oxidized, allowing not only morphological observation but also quantitative measurement by flow cytometry.

\section{ACKNOWLEDGEMENTS}

This study was supported by a Grant-in-Aid for Scientific Research (C) from Japan Society for the Promotion of Science (JSPS), No.19591145 for Dr. H. Seguchi and Ms. Eva Garcia del Saz.

HYOGO, A.; KOBAYASHI, T.; GARCIA DEL SAZ, E. \& SEGUCHI, H. Efectos antioxidantes del ácido protocatéquico, ácido ferúlico y el ácido caféico en los neutrófilos humanos con una sustancia fluorescente. Int. J. Morphol., 28(3):911-920, 2010.

RESUMEN: Los neutrófilos humanos estimulados por forbol-miristato-acetato (PMA), un activador de la proteína quinasa $\mathrm{C}$, producen oxígeno activo por la NADPH oxidasa en las estructuras intracelulares. Hemos añadido diacetato de 2', 7dihidro dicloro fluoresceína ( $\left.\mathrm{H}_{2} \mathrm{DCFDA}\right)$, que emite fluorescencia cuando se oxida con las especies de oxígeno activo, a neutrófilos para producir oxígeno activo, a fin de investigar el efecto antioxidante del ácido protocatéquico, el ácido ferúlico y el ácido cafeico que pertenecen a polifenoles y se distribuyen ampliamente entre las plantas. Particularmente, nos enfocamos en examinar si estas sustancias capturan y eliminan el oxígeno 
activo dentro o fuera del citoplasma de neutrófilos y si estas sustancias inhiben la NADPH oxidasa. La microscopia de fluorescencia demostró que las estructuras intracelulares positivas a fluorescencia disminuyeron en los neutrófilos mediante la estimulación de la PMA y exposición a un antioxidante. La medición cuantitativa por citometría de flujo reveló que la intensidad de fluorescencia en los neutrófilos, expuestos al ácido protocatéquico, el ácido ferúlico, o el ácido cafeico, se redujo un $62,9 \%, 71,4 \%$ y $86,1 \%$, respectivamente, en comparación con las estimuladas por PMA pero no expuestas a un antioxidante. A juzgar desde la microscopía de fluorescencia y la citometría de flujo, estos antioxidantes no tuvieron efectos sobre la morfología de los neutrófilos. Por otra parte, la intensidad de fluorescencia del oxígeno activo liberado por los neutrófilos se redujeron un $81,4 \%, 46,7 \%$ y $27,4 \%$, respectivamente. El DPI (difenilenoiodonio), un inhibidor específico de la NADPH oxidasa, inhibió a la enzima en el 92,1\% en los neutrófilos estimulados por PMA. El ácido protocatéquico, el ácido ferúlico y el ácido caféico inhiben la enzima en un $36,5 \%, 54,6 \%$ y $27,4 \%$, respectivamente. Estos resultados demuestran que el ácido protocatéquico, el ácido ferúlico y ácido caféico capturan y eliminan el oxígeno activo, producido por el PMA estimulado por neutrófilos, intracelular y extracelularmente. Además, estos antioxidantes inhiben parcialmente la actividad NADPH oxidasa.

PALABRAS CLAVE: Efectos antioxidantes; Polifenoles; Neutrófilos humanos; Citometría de flujo.

\section{REFERENCES}

Babior, B. M. Oxygen-dependent microbial killing by phagocytes (first of two parts). N. Engl. J. Med., 298:65968, 1978.

Babior M. B. NADPH oxidase: an update. Blood, 93:146476, 1999.

Cross, A. R. \& Jones, O. T. Enzymic mechanisms of superoxide production. Biochim. Biophys. Acta, 1057(3):281-98, 1991.

Doussière, J. \& Vignais, P. V. Diphenylene iodonium as an inhibitor of the NADPH oxidase complex of bovine neutrophils. Factors controlling the inhibitory potency of diphenylene iodonium in a cell-free system of oxidase activation. Eur. J. Biochem., 208:61-71, 1992.

Freeman, B. A. \& Crapo, J. D. Biology of disease: free radicals and tissue injury. Lab. Invest., 47(5):412-26, 1982.

Kern, S. M.; Bennett, R. N.; Needs, P. W.; Mellon, F. A.; Krron, P. A. \& Garcia-Conesa, M. T. Characterization of metabolites of hydroxycinnamates in the in vitro model of human small intestinal epithelium caco- 2 cells. J. Agric. Food Chem., 51:7884-91, 2003.

Kobayashi, H. \& Robinson, J. M. A novel intracellular compartment with unusual secretory properties in human neutrophils. J. Cell Biol., 113:743-56, 1991.

Kobayashi, T.; Robinson, J. M. \& Seguchi, H. Identification of intracellular sites of superoxide production in stimulated neutrophils. J. Cell Sci., 111:81-91, 1998.

Kobayashi, T. \& Seguchi, H. Novel insight into current models of NADPH oxidase regulation, assembly and localization in human polymorphonuclear leukocytes. Histol. Histoopathol., 14:1295-308, 1999.

Kobayashi, H.; Tsunawaki, S. \& Seguchi, H. Evaluation of the process for superoxide production by NADPH oxidase in human neutrophils: evidence for cytoplasmic superoxide. Redox Rep., 6:27-36, 2001.

Kobayashi, T.; Zinchuk, V. S.; Okada, T.; Wakiguchi, H.; Kurashige, T.; Takatsuji, H. \& Seguchi, H. A simple approach for the analysis of intracellular movement of oxidant-producing intracellular compartments in living human neutrophils. Histochem. Cell Biol., 113:251-7, 2000 .

Konishi, Y. \& Kobayashi, S. Transepithelial transport of chlorogenic acid, caffeic acid, and their colonic metabolites in intestinal Caco-2 cell monolayers. $J$. Agric. Food Chem., 52:2518-26, 2004.

Kwon, E. Y.; Cho, Y. Y.; Do, G. M.; Kim, H. J.; Jeon, S. M.; Park, Y. B.; Lee, M. K.; Min, T. S. \& Choi, M. S. Actions of ferulic acid and vitamin $\mathrm{E}$ on prevention of hypercholesterolemia and atherogenic lesion formation in apolipoprotein E-deficient mice. J. Med. Food, 12:996-1003, 2009.

Lin H. H.; Chen, J. H.; Huang, C. C. \& Wang, C. J. Apoptotic effect of 3,4-dihyroxybenzoic acid on human gastric carcinoma cells involving JNK/p38 MAPK signaling activation. Int. J. Cancer, 120:2306-16, 2007.

McCord, J. M. \& Fridovich, L. Superoxide dismutase. An enzymic function for erythrocuprein (hemocuprein). J. Biol. Chem., 244:6049-55, 1969.

Messey, V. The microestimation of succinate and the extinction coefficient of cytochrome c. Biochim. Biophys. Acta, 34:255-6, 1959. 
HYOGO, A.; KOBAYASHI, T.; GARCIA DEL SAZ, E. \& SEGUCHI, H. Antioxidant effects of protocatechuic acid, ferulic acid, and caffeic acid in human neutrophils using a fluorescent substance. Int. J. Morphol., 28(3):911-920, 2010.

Nakamura, Y.; Torikai, K.; Ohto, Y.; Murakami, A.; Tanaka, T. \& Ohigashi, H. A simple phenolic antioxidant protocatechuic acid enhances tumor promotion and oxidative stress in female ICR mouse skin: dose-and timing-dependent enhancement and involvement of bioactivation by tyrosinase. Carcinogenesis, 21:1899907, 2000.

Nishikawa, M.; Takakura, Y. \& Hashida M. Pharmacokinetic considerations regarding non-viral cancer gene therapy. Cancer Sci., 99(5):856-62, 2008.

Nishizuka, S. Studies and perspectives of protein kinase C. Science, 233:305-12, 1986.

Sakakibara, H.; Honda, Y.; Nakagawa, S.; Ashida, H. \& Kanazawa, K. Simultaneous determination of all polyphenols in vegetables, fruits, and teas. J. Agric. Food Chem., 51:571-81, 2003.

Robinson, J. M. Does O2 photoreduction occur within chloroplasts in vivo? Physiol. Phi., 72:666-80, 1988.

Robinson, J. M. \& Badwey J. A. The NADPH oxidase complex of phagocytic leukocytes: A biochemical and cytochemical view. Histochem. Cell Biol., 103:163-80, 1995.
Correspondence to:

Harumichi Seguchi, M.D., Ph.D.

Professor of Anatomy and Physiology

Department of Health

Sports and Nutrition

Faculty of Health and Welfare

Kobe Women's University

4-7-2, Minatojima-nakamachi, Chuo-ku

Kobe 650-0046

JAPAN

Tel. \& Fax. 078-303-4809

Email: seguchih@suma.kobe-wu.ac.jp

Received: 14-07-2010

Accepted: 25-07-2010 